\title{
The value of private sector business credit information sharing: The US case
}

\author{
Jarl G. Kallberg a , Gregory F. Udell ${ }^{\text {b,* }}$ \\ ${ }^{a}$ The Stern School of Business, New York University, New York, NY 10012, USA \\ ${ }^{\mathrm{b}}$ Finance Department, Kelley School of Business, Indiana University, 1309 East Tenth Street, \\ Bloomington, IN 47405-1701, USA
}

\begin{abstract}
This paper investigates the value added by private information exchanges that share information on business payment performance. We discuss how this information is collected and disseminated by the world's largest private information broker, Dun \& Bradstreet. We provide the first empirical examination of the importance of this information at the lending decision level. Our findings indicate that exchange-generated information provides significant explanatory power in failure prediction models controlling for other credit information that is easily available to lenders. Our study complements the work of Jappelli and Pagano [Information sharing, lending and defaults; Cross country evidence, Centre for Economic Policy Research, Discussion Paper 2184, 1999] who find in cross-country macro level tests that information exchanges add value.
\end{abstract}

(C) 2003 Elsevier Science B.V. All rights reserved.

JEL classification: $\mathrm{G} 23 ; \mathrm{G} 32$

Keywords: Information exchange; Information sharing; Lending

\section{Introduction}

The extension of business credit is problematic because of the information wedge between lenders and borrowers. Informational opacity significantly affects business access to external finance and its cost, particularly for smaller companies. These firms are excluded from public debt and equity markets and are substantially

\footnotetext{
${ }^{*}$ Corresponding author. Tel.: +1-812-855-3394; fax: +1-812-855-5875.

E-mail address: gudell@indiana.edu (G.F. Udell).
} 
dependent on private debt markets for external finance. ${ }^{1}$ These private debt markets employ an extensive array of mechanisms to solve information problems. Efforts by financial economists to explain these solutions have led to the modern information-based theory of financial intermediation and have provided the theoretical motivation of contractual tools such as collateral, guarantees, covenants and maturity.

One very important market tool has been ignored in the academic literature until quite recently - the exchange of credit information by lenders, particularly through formal exchange mechanisms. The paucity of research in this area is remarkable given the widespread use of formal information exchanges. Information exchanges can be formalized in one of two ways: (i) an exchange mechanism imposed by government regulation, or (ii) a voluntary exchange mechanism. Regulation-imposed exchange mechanisms often take the form of "public credit registers" managed by central banks. Under these programs information reporting is compulsory. Voluntary exchange mechanisms can take the form of cooperatives or private information exchanges, such as the world's largest: the Dun \& Bradstreet Corporation $(\mathrm{D} \& \mathrm{~B})$.

One of the goals of our paper is to empirically explore the value of business-tobusiness voluntary information exchange mechanisms using the US as an example. We focus exclusively on the commercial credit market and the associated businessto-business exchange of credit information by examining two fundamental questions. ${ }^{2}$ First, is the formal exchange of business credit information valuable to creditors when they conduct their borrower due diligence? Second, does the value of this information extend beyond just the efficient dissemination of otherwise readily available information? We address these questions by analyzing the power of exchange-generated information in assessing borrower quality. Specifically, we empirically test the hypothesis that exchange-generated information is a significant explanatory variable in a firm failure prediction model controlling for information that would normally otherwise be available to a commercial lender, such as firm characteristics and financial statement data. We use a database from D\&B that allows us to analyze these questions at the credit decision making level, i.e., at the borrowing-firm level.

Our analysis complements and extends the empirical work of Jappelli and Pagano (1999) who also empirically address the issue of the value of formal information exchanges. In particular, they use a macro approach to analyze the cross-country association between the presence of formal information exchanges and measures of

\footnotetext{
${ }^{1}$ Small firms, however, obtain a substantial portion of their overall funding from insider equity infusions from the startup team, family and friends (about half on average). Other than a relatively small number of very high growth startup firms that access the angel and formal venture capital markets, small firms are almost entirely dependent on the private debt markets for external funding. The two biggest categories of private external debt are trade credit and financial institutions (Berger and Udell, 1998).

2 Similar information exchange mechanisms exist in the consumer credit market, including involuntary credit registries and voluntary consumer credit bureaus. Our focus in this paper, however, is entirely on the commercial market and business-to-business information exchange.
} 
aggregate economic performance. Like Jappelli and Pagano (1999), we find evidence consistent with the proposition that formal information sharing contributes positively to the functioning of credit markets. Our approach, however, is quite different from theirs. We are the first to take a micro approach by analyzing the value of information exchange-generated information at the credit decision-making level.

Our focus on the US may be particularly interesting because the market for business-to-business information exchange is dominated by one company, the world's largest formal information exchange, D\&B. A secondary objective of this paper is to describe how formal information exchanges like D\&B operate. It is generally accepted that formal credit information sharing is characterized by significant economies of scale (e.g., Pagano and Jappelli, 1993). Therefore, it may be particularly interesting to analyze the collection, dissemination, and value of information generated by the organization that is likely the most scale-efficient information exchange.

By analyzing a private business information exchange we also shed light on a related issue. Voluntary private information exchanges differ in some important ways from public credit registries. One difference is coverage. Participation in public credit registers is typically compulsory, which means that suppliers of credit (e.g., banks, finance companies, trade creditors) are obligated to furnish payment performance information on their customers/borrowers. This is decidedly not the case with private information exchanges. ${ }^{3}$ Specifically, credit suppliers will only share information with a private information exchange to the extent that it is in their financial interest to do so. Thus, the value of information provided by information exchanges will depend on the extent to which they can profitably offer incentives that encourage sufficient coverage.

It is also possible that collection bias in the data diminishes the quality of the information provided by information exchanges. For example, smaller credit issuers may be under-represented in an exchange's database. This may be problematic if business financial distress manifests itself in slowness in paying smaller creditors before it is reflected in slowness in paying larger creditors. Arguably the problems of coverage and bias may be more acute in voluntary information exchanges than public credit registries. ${ }^{4}$ Finally, all information exchanges must solve a credibility problem. That is, like all financial intermediaries they must convince their customers that their information is reliable. Arguably, public information exchanges, which are often run by central banks, have an advantage in this regard. Our finding that the information generated by a private information exchange is significantly informative, suggests that these credibility problems are solvable.

\footnotetext{
${ }^{3}$ Almost all firms enter D\&B's database as a result of a credit inquiry by one of D\&B's customers.

${ }^{4}$ The problems of coverage and basis, however, may not be exclusive to private information exchanges. As noted by Jappelli and Pagano (1999), some public credit registers limit compulsory participation to amounts in excess of credit thresholds. In addition, public credit registers differ in terms of the types of information collected.
} 
Our paper is organized as follows. We begin our analysis with an overview of the relevant literature on the economics of information sharing. We also examine the extent to which this literature makes a distinction between public credit registers and voluntary information exchanges. In Section 3 we examine business information sharing in the US, focusing on the dominant player, D\&B. D\&B has collected information on over 70 million businesses in over 219 countries (D\&B, 2002). Because formal information exchange has received so little attention in the academic literature we provide some detail on D\&B's production process and the specific nature of its output. In Section 4, we empirically examine the value of D\&B's business credit information by analyzing its power in failure prediction models. Specifically, we analyze whether exchange-generated information available one year prior to a success/ failure outcome is significant in discriminating between failed and non-failed firms controlling for other information that would have been readily available to creditors to predict success. We construct a sample of firms in the retail industry that failed over a one-year period, and a sample of comparable firms that survived (i.e., were in existence one year later). To be included in the sample, sufficient information about the firm's financial condition and exchange-generated information about the firm had to be available prior to the success/failure outcome. Our selection criteria produced a sample of 241 failed firms and 2482 non-failed firms. We offer concluding comments in Section 5.

\section{The economics of business credit information sharing}

Somewhat surprisingly, only recently has the academic literature examined one of the most common and important mechanisms available to manage informational opacity: formal information sharing mechanisms. In addition to producing information about their own borrowers, lenders can share information about their borrowers with other creditors through formal sharing arrangements. As noted above, this can be extruded through a number of different vehicles, the most significant being public credit registers and private information exchanges. ${ }^{5}$ The use of these mechanisms is widespread; Jappelli and Pagano (1999) report statistics on the extent of information sharing. In response to questionnaires sent to 49 countries, they found that 19 countries had public credit registers and 29 countries had voluntary information exchanges (i.e., "credit bureaus"). ${ }^{67}$

\footnotetext{
${ }^{5}$ Other mechanisms include, for example, industries that share various types of credit information through pooling arrangements conducted through trade associations such as the Robert Morris Associates in the US commercial banking and the Commercial Finance Association in the US asset-based lending industry.

${ }^{6}$ The data reported in Jappelli and Pagano (1999) did not distinguish between consumer and commercial information sharing.

${ }^{7}$ Jappelli and Pagano (1999) provide more extensive information on public credit registers and private information exchanges and the differences between the two. They also analyze the substitutability between these two vehicles and the conditions under which public credit registers are likely to be formed.
} 
Information sharing is useful both at the origination stage and after credit has been extended. At the origination stage, information sharing can augment the due diligence process in mitigating problems of adverse selection. Using a pure adverse selection model, Pagano and Jappelli (1993) find that information sharing improves the borrower pool, reduces loan interest rates and decreases loan defaults.

Information sharing is also valuable in addressing moral hazard problems. Padilla and Pagano (1997) show that information sharing can have an incentive effect on borrower behavior. In their model, lenders are endowed with private information about borrower quality that gives them a degree of market power over their borrowers. However, by precommitting to exchange information about borrower quality, lenders reduce their ability to extract future informational rents. By reducing the holdup problem, information sharing has positive incentive effects, encouraging borrowers to expend more effort. Padilla and Pagano (1999) show that even in the absence of holdup problems, information sharing can have a disciplinary effect when lenders exchange information about past defaults instead of exchanging information about borrower types.

In the extant models of information sharing (Pagano and Jappelli, 1993; Padilla and Pagano, 1997; Padilla and Pagano, 1999), there is only one lender per borrower. These models derive their adverse selection effects and incentive effects through a multi-period lending environment. For example, in Padilla and Pagano (1997), lender precommitment to share information about borrower quality in the first period forces competition in the second period, reducing opportunistic lender behavior. These models do not consider an environment where firms borrow simultaneously from multiple lenders.

Two papers have modeled information exchange in the context of multiple lenders. Klein (1992) creates a game-theoretic formulation of the problem of creating a credit bureau. More in the spirit of trading models that characterize when market participants willingly share valuable, private information is Kallberg and Udell (2002). A key distinction between the two approaches is that Klein assumes that credit grantors cannot access credit bureau data unless they also submit their credit experiences to the bureau. This assumption is not true in practice either for consumer or commercial credit bureaus. Both models show the value of economies of scale as more lenders contribute their payment experiences to the credit bureau.

In an environment of multiple lenders, information sharing mechanisms may be quite valuable in reducing coordination costs. The importance of coordination costs among multiple lenders in financing larger firms has been identified in the finance literature. Gilson et al. (1990), for example, argue that private debt contracts may reduce costs associated with financial distress because coordination among private lenders may be less costly than coordination among public bondholders. However, coordination problems among lenders may be even more important in small firm finance where firms are typically much more informationally opaque and their external financing is widely dispersed among many creditors. The dispersion in small firm financing stems from the dependence small firms have on trade credit and the fact that trade credit is typically spread among many suppliers. Recent evidence suggests 
that trade credit may be the most important source of external finance to small businesses (Berger and Udell, 1998). ${ }^{8,9}$

Arguably formal information sharing among lenders to small business, particularly trade suppliers, may be the most valuable (and possibly the only) mechanism available for reducing coordination costs. It may afford trade creditors (in addition to any bank lenders ${ }^{10}$ ) an opportunity to observe in real time the performance of their borrowers on contracts with other creditors. It seems plausible that formal information sharing among trade creditors would mitigate adverse selection and moral hazard problems in a manner similar to the single lender models discussed above. ${ }^{11}$ The value of formal information sharing, of course, depends on the quality of information provided, which we address in the empirical section of this paper.

In addition to mitigating adverse selection and moral hazard problems, formal information sharing mechanisms could encourage a more competitive loan market. This occurs, for instance in the Padilla and Pagano (1997) model, because information sharing reduces the extraction of informational rents. In their two-period model, a holdup problem is created because lenders are endowed with an informational advantage stemming from private information about their borrowers. As noted earlier, the incentive effects derived in their model are a result of competition, which discourages predatory pricing in the second period.

In order for these mechanisms to deliver the benefits noted above, not only must the information they provide be of a type that is useful to lenders, it must also be reliable. Presumably in the case of public credit registers the credibility of the institution itself (i.e., the credit register) is less of an issue. With only one exception (Finland), Jappelli and Pagano (1999) report that public credit registers are managed

\footnotetext{
${ }^{8}$ Based on the 1993 National Survey of Small Business Finance, Berger and Udell (1998) calculate that small firms (firms with less than 500 employees) finance nearly $16 \%$ of their assets with trade credit. This is only exceeded by private equity at about $50 \%$ (most of which is internally provided) and bank financing at about $19 \%$. However, they also note that most bank debt is either guaranteed by the owners or collateralized by the owners' assets. Thus, most of the bank debt is also effectively internal equity. Therefore, the largest source of purely external finance is trade credit.

${ }^{9}$ There is a growing literature on the importance of trade credit that suggests that trade creditors may have certain contracting advantages over traditional financial intermediaries. These advantages include information acquisition (Ferris, 1981; Smith, 1987; Brennan et al., 1988; Biais and Gollier, 1997; Petersen and Rajan, 1997) imposing incentives through threats on withholding supplies (Biais and Gollier, 1997) and reduction of liquidation costs in bankruptcy (Mian and Smith, 1992; Petersen and Rajan, 1997). There is also evidence that trade credit is particularly important to firms with weak banking relationships (Petersen and Rajan, 1994, 1995, 1997) and firms that are growing quickly (Petersen and Rajan, 1997). In addition, these advantages may be even greater in the informationally poor environments of formerly centralized economies and lessor developed countries where banks may look to trade creditors for certification of borrower credit quality (Cook, 1999).

${ }^{10}$ Berger and Udell (1995) report that most small firms that obtain working capital financing do so from a single bank.

${ }^{11}$ The simultaneous observation of performance across multiple loan contracts (via formal information sharing) coupled with the continuous recontracting nature of trade credit may be analogous to the enforcement of cross-default covenants found in multiple lender financing for large firms.
} 
either by central banks or banking supervisory authorities. ${ }^{12}$ In addition, as agents of the government public credit registers may have an advantage in ensuring that lenders supply accurate information.

Credibility, however, is very much an issue with private information exchanges such as D\&B. At first blush it might appear that we could appeal to the relatively recent literature on the theory of financial intermediation (e.g., Diamond, 1984; Boyd and Prescott, 1986). However, in these models financial intermediaries invest in the information they produce. Since financial intermediaries are widely diversified, any shirking would be revealed in a failure to deliver promised returns to their depositors. This, of course, is not the case with private information exchanges that, indeed, act only as brokers. Market solutions, however, may be available. In the two-period, single-lender (per-period) model of Padilla and Pagano (1997), borrowers can force deviating lenders to share accurate information so long as information can be transmitted across generations costlessly. In a simultaneous multi-lender environment, borrowers could discourage a deviating lender and/or a shirking private information broker, by reporting instances of false or inaccurate credit reporting. Thus, reputation building would appear to be important to the viability of a private information exchange in a fashion similar to credit rating agencies in the bond market (see Cantor and Packer, 1994). Furthermore, the threat of litigation with punitive damages would enhance this enforcement mechanism. ${ }^{13}$ Our empirical finding that information generated by a private (voluntary) information exchange is informative suggests that these credibility problems can be solved in the marketplace.

The only empirical study of the value of business information exchanges, of which we are aware, is Jappelli and Pagano (1999) who analyze the extent to which the presence of formal information sharing impacts aggregate economic performance. If information sharing represents an efficient vehicle for reducing contracting costs associated with asymmetric information, then we would expect more credit availability and a lower cost of capital in countries that had either public credit bureaus or private information exchanges. This study provides evidence that countries with more intense and established formal information sharing, either via credit registries or voluntary information exchanges, exhibit greater bank lending as scaled by GNP. They also find evidence that credit risk is negatively related to measures of formal information sharing. This suggests an important policy issue: countries in which voluntary exchange mechanisms have not emerged may find it advantageous to establish a public credit register. Jappelli and Pagano (1999) shed further light on this policy issue by presenting empirical evidence suggesting that public credit registers may be substitutes for voluntary information exchanges. Specifically, they find that

\footnotetext{
${ }^{12}$ This is not to say that these government organizations are devoid of agency problems, only that these problems are probably of second-order importance relative to the credibility problems associated with private information exchanges. Specifically, it seems reasonable to assume that the objective function of central banks is more likely to be aligned with maximizing social welfare.

${ }^{13}$ See Boot et al. (1991) for a model in which litigation and the possibility of punitive damages enforces an equilibrium in which financial intermediation is sustainable.
} 
countries with voluntary credit information exchanges are less likely to start a public credit register.

Our study augments Jappelli and Pagano (1999) by empirically examining whether exchange-generated information is informative in analyzing individual borrowers. Like Jappelli and Pagano (1999) we are interested in the value added by formal information exchanges. However, unlike their study, we examine the value of exchange-generated information at the micro-level. We specifically test whether exchange-generated information is useful in predicting borrower failure controlling for other types information that would be available to lenders. These control variables enable us to measure the incremental value of exchange-generated information. Indirectly, we also weigh in on the issue of public versus private information exchanges. Our finding that information produced by a private information exchange is valuable, suggests that private information exchanges are capable of solving the credibility problems associated with their type of intermediation services.

\section{Private information exchanges - The US case}

To focus the following discussion we devote most of our attention to the role and the credit data supplied by the Business Credit Services division of D\&B. The company was created by the 1933 merger between R.G. Dun \& Co. (founded in New York in 1841) and the Bradstreet Company (founded in 1849 in Cincinnati), and is today by far the dominant business information exchange in the US. ${ }^{14}$ D\&B's major competitor is Experian, although there are a number of industry groups that pool credit information for their members. Although our focus is on the US, D\&B operates worldwide and its database contains information on about 70 million companies in 214 countries (D\&B, 2002). The most inclusive product offered by D\&B is its D\&B Comprehensive Report (CR), which contains a wide variety of qualitative and quantitative data on a subject firm. D\&B also offers other reports that focus on specific aspects of the firm. For decades these reports have been an essential part of commercial credit granting. Beginning in the late 1980s D\&B also began selling data "by the pound" so that customers with automated credit processing systems, rather than purchasing reports, could purchase the specific elements in the D\&B database that their application required. Also today a number of companies (e.g., Oracle; Siebel Systems; Deloitt Consulting; Open Ratings; SAS Institute; SAP) with whom D\&B has partnered, integrate D\&B data into their own systems.

D\&B collects many different types of information about a company's business activities including its size, history, public filings (liens, lawsuits, judgements, bankruptcy) and, for some companies, financial statements. D\&B also assigns businesses a rating, which is roughly the analogue of a bond rating in the public debt markets. Arguably, however, the most valuable data that D\&B collects is payment history, the vast majority of which is trade payment history. Most small businesses

\footnotetext{
${ }^{14}$ Consumer credit information is provided in the US by the three major credit bureaus.
} 
borrow from at most one bank (see Berger and Udell, 1998) so it is relatively easy for a creditor to obtain information about how a company is performing on its bank loan obligations. Most companies, however, obtain trade credit from numerous suppliers, so information on trade credit is much more costly and problematic to obtain. Moreover, in aggregate, trade creditors finance nearly as much of small business assets in the US as commercial banks - 16\% versus 19\% (Berger and Udell, 1998).

While trade payment information collected by D\&B today is quantitative in nature, this was not the case historically. The antecedents of D\&B and its competitors in the 19th century relied on a network of correspondents to collect relatively "soft", information about firms. While this information was subsequently codified into a rating, the inputs into this rating were decidedly qualitative in nature (Carruthers and Cohen, 2000). This stands in sharp contrast to hard payment history information collected by D\&B today. Payment information is typically summarized in a statistic called the PAYDEX score. PAYDEX is a number between 0 and 100, which translates (approximately) into the average number of days past due for the given firm's last year of trade experiences. The PAYDEX score thus characterizes the turnover behavior of debt payment information furnished to D\&B by suppliers of trade credit and other forms of business debt. More detail on PAYDEX is provided later in this section.

Trade creditors and financial institutions use business credit reports such as those generated by D\&B in evaluating the creditworthiness of both large and small customers. Asset-based lenders, who lend against accounts receivable (i.e., factors, commercial finance companies and the asset-based lending divisions of commercial banks) will use credit reports to evaluate specific receivables. ${ }^{15}$ Lenders extending credit in the $\$ 3000$ to $\$ 100,000$ range may rely exclusively on payment history obtained from D\&B, such as PAYDEX, rather than undertaking a more expensive, time-consuming and often infeasible investigation involving analyzing borrower financial statements and checking with multiple creditors and other sources. Often the timeliness of the decision is important, particularly when businesses use automated techniques in making their credit decisions. These types of automated credit granting procedures can often render accept or reject decisions on $90 \%$ or more of all business and consumer credit applications within one minute of initiation. These techniques have been given a huge impetus from the growth of Internet business-tobusiness transactions.

D\&B reports and data represent a relatively low cost source of credit information relative to the cost of independent due diligence. A substantial amount of the data that D\&B collects could be gathered by an individual credit grantor, although the cost of collecting these data collectively likely exceeds the cost of obtaining it from D\&B (e.g., data on UCC filings, bankruptcies, tax liens, judgements). Financial statement information, which is contained in several types of D\&B reports, is otherwise publicly available for companies that issue registered securities and could be available privately upon lender request - if the borrower agrees to provide it. The

\footnotetext{
${ }^{15}$ See Clarke (1996, p. 39).
} 
trade payment information, however, would be prohibitively expensive for creditors to gather on their own. This is the area, for reasons discussed below, where an information exchange enjoys the benefits of significant economies of scale.

D\&B collects its information from a variety of sources. Some of the descriptive information comes from public filings (e.g., through bankruptcy filings, UCC filings, corporate charters etc.). Other information is generated by D\&B's own correspondents who gather data on firms by visiting and telephoning the firm's principals. ${ }^{16}$ Trade payment information is obtained from other corporations that provide $\mathrm{D} \& \mathrm{~B}$ with the payment history of their own customers. For example, D\&B might collect payment information on the XYZ Company from 50 of XYZ Company's suppliers. These 50 suppliers regularly submit electronically their accounts receivable data to D\&B. D\&B then extracts information on the XYZ Company from each of these accounts receivable databases and adds it to its database on the XYZ Company.

Appendix A summarizes the information contained in the sample CR on D\&B's website. This sample report is eleven pages in length and contains extensive information on a variety of different dimensions. As shown in Appendix A, D\&B rates the subject firm on the basis of its "financial stress class" and its "credit score class". The former is a measure of the firm's bankruptcy potential and the latter is a measure of the firm's probability of being severely delinquent. Following this is an "Executive Summary", which provides an overall summary of key information in the report. The report continues with detailed information. Descriptive information about the subject firm is contained under various topic headings. For example, the report provides information about the firm's history, biographical information about the firm's officers, information about the firm's operations, and information about any significant event that might affect the firm's current condition (e.g., a recent fire in the firm's facilities). Information on public filings (i.e., bankruptcy proceedings, judgements, liens, suits and UCC filings) are provided both in summary fashion and in detail at the individual filing level. Selected financial statement information is provided, if available, including sales, net worth and working capital.

To many credit grantors, the most important part of these reports is the information relating to how well the subject firm is meeting its credit obligations. This includes detailed information about the firm's payment experiences. For example, payment information includes the number of experiences in the database, total amount, and percent paying "within terms" (i.e., on time) and is categorized by size of credit (e.g., over $\$ 100,000, \$ 50,000-\$ 99,999$, etc.). Payment information is also broken down by industry. Specifically, for each industry information is provided on the dollar amount extended by that industry, the highest credit provided by any creditor in that industry, the percent of payment experiences "within terms", and specific information on slow payments (i.e., percent slow 1-30 days, percent slow 31-60 days, percent slow 61-90 days, and percent slow over 90 days). In this sample

\footnotetext{
${ }^{16}$ In the 19th century, these correspondents who were often lawyers, included such luminaries as Abraham Lincoln, Woodrow Wilson and Calvin Coolidge. A brief history of D\&B is included in Newman (1997).
} 
CR, D\&B provide payment information broken down by 93 different industry categories.

Arguably the most important piece of information provided by D\&B is the PAYDEX score. In our subsequent statistical analysis, it is the most important variable (as determined by a $t$-test of significant differences between the means of the failed and non-failed firms). PAYDEX, roughly stated, gives a composite evaluation of the most recent 13 months of a firm's reported payment history. This variable can be interpreted as average days past due (dollar-weighted), although the actual calculation involves more than just this measurement. When PAYDEX is calculated, efforts are made to use "representative" trade experiences. Appendix B gives a breakdown of PAYDEX. For example, a score of 80 corresponds to prompt payment; a PAYDEX of 70 would correspond to average payments slow 15 days; a score of 40 would correspond to payments late 60 days. This variable is also used by credit grantors in comparison with industry payment norms as well in analyses of its current and historic values.

\section{An empirical investigation of the value of third-party credit information}

In this section we use D\&B data to empirically investigate the value of the information that private information exchanges produce. As noted earlier, our analysis complements and extends the extant empirical work on information sharing, particularly that of Jappelli and Pagano (1999), who analyze the impact of information sharing (business and consumer combined) on measures of aggregate economic performance. Our study, however, focuses on the value added by information exchanges at the micro level (i.e., the individual credit decision-making level) rather than at the macro level. Our objective is to analyze whether data provided by D\&B is informative with respect to assessing borrower quality.

We specifically examine three issues. First: Is credit information sharing in general, and business credit information in particular, a valuable mechanism for solving information problems in lending? A finding that D\&B's mercantile credit information is helpful in predicting distress supports the proposition that information sharing in general is a worthwhile activity. Second: Does the value of information sold by private information exchanges extend beyond just the efficient dissemination of otherwise publicly available information? A finding that D\&B's mercantile credit information adds predictive power beyond that contained in financial statements would give us a measure of just how valuable business information sharing is. Third, can private information exchanges solve the credibility problems associated with their role as an information intermediary? Again, a finding that D\&B's mercantile credit information adds significant value to lender-users would argue that they can. Our focus here is exclusively on business exchange-generated information unlike Jappelli and Pagano (1999) who consider both consumer and business information. Our methodological approach is to examine whether D\&B's payment experience information adds power in a failure prediction model controlling for information contained in standard financial statements and other sources available to creditors. 
The statistical analysis of firm failure has been an active area of financial research since the mid 1960s. Beginning with the univariate analysis of Beaver (1966) and the discriminant analysis application of Altman (1968), a very broad range of empirical, methodological and economic issues have been analyzed. Concurrently, the practical applications of these models have rapidly grown. These applications have ranged from loan granting decisions (e.g., Orgler, 1970; Edmister, 1972), to bond ratings (e.g., Kaplan and Urwitz, 1979), to bank failures (e.g., Martin, 1977) and to estimates of bond mortality (e.g., Queen and Roll, 1987; Altman, 1989; and Asquith et al., 1989). The standard methodology has been based on classification (fixed-horizon) models. A number of studies have used survival analysis and its extensions, which generate failure probabilities over a horizon, e.g., a firm's failure probability for each point in time from 1 to 10 years (see Wilson and Kallberg, 1991; Shumway, 2001). Newer approaches to predicting bankruptcies have employed more sophisticated techniques. Examples are Theodossiou (1993), who uses a dynamic approach to testing for shifts in the mean of a time series to predict business failures, Cheng and Titterington (1994) who survey neural net approaches, and Moon and Stotsky (1993), who use smooth simulated maximum likelihood estimation. These studies are almost all based upon financial statement data, typically various financial ratios. Ours is the first academic study that uses third-party credit information in the bankruptcy prediction model. ${ }^{17}$

Data for our study comes from the Dun \& Bradstreet data base on firms in the retailing SIC group (firms with primary SICs of 52, 53, 54, 56, 57 and 59). Failed firms were selected from those that filed for bankruptcy in 1988 and for which sufficient financial data existed in the D\&B database. We focus on this industry group for a number of reasons: It simplifies the presentation of the results; it mitigates industry effects; and, it analyzes an industry that has featured some well-publicized failures. To be included in the data set, the firm must have the basic components of the balance sheet present in each of the three years prior to the failed/non-failed classification. Accounting data are collected for the three years prior to the failed/ non-failed classification. Given that income statement data is much less frequently reported in the D\&B database (perhaps because most firms feel these data are more proprietary than balance sheet data), most ratios driven solely by income statement or cash flow data could not be used in our analysis. ${ }^{18}$ These data restrictions resulted in a sample of 241 failed firms. A random sample of 2482 non-failed firms meeting the same data restrictions was also drawn. The total sample size is thus

\footnotetext{
${ }^{17}$ Keasey and Watson (1987) is closer in spirit to the research in this paper. They use a sample of 146 firms with financial statement data and information on the age of company, the directors and auditors, lags in reporting to Companies House and whether or not any of the firm's assets secure a bank loan. They showed that these additional variables improved the bankruptcy prediction model significantly.

${ }^{18}$ We note a weakness with our data set. Since all the financial data are obtained from D\&B for consistency and practical reasons, we have only information for firms that voluntarily allow D\&B to publish their financial statement data. This induces some bias. More importantly, firms are very reluctant, for competitive reasons, to submit income statement data to D\&B. These data are so sparse in our sample that they could not be used in our empirical analysis. Clearly, a fairer test would use much more complete financial data.
} 
2723 firms and the overall failure rate is $8.8 \%$. Three-fourths of this sample was used to estimate the model; the remainder was used as a holdout validation sample.

It is important not to misinterpret the failure rates quoted. The data set includes all failed firms meeting the outlined data requirements and a sample of non-failed firms meeting the same restrictions. Not all failed firms within these SIC groups are represented because some may not be in the D\&B database and others may be in the database but have insufficient data. This censoring has a greater effect on the failed than on non-failed firms. As the data below indicate, failed firms tend to be younger than non-failed firms and, for precisely this reason, are therefore somewhat less likely to have complete information available. While it is difficult to get precise numbers of firms in business in 1989 in the retail trade SICs (5200 5999), D\&B had credit data available on 1,433,358 firms. ${ }^{19}$

Our analysis utilizes two categories of data on this sample of firms and examines their ability to discriminate between failed and non-failed firms. The first category is payment information, which we capture in the summary statistic PAYDEX. As described above PAYDEX summarizes the payment history information. Our testable hypothesis - that private information exchanges generate valuable information for creditors - will be reflected in whether the coefficient on this variable is significant. The univariate relationship between PAYDEX and firm failure is reflected in Fig. 1, which shows that firm failure rate is highly negatively correlated with PAYDEX. We include a dummy variable, PAYDUM, if PAYDEX is not available for a firm in our sample. The second category of data consists of financial statements, descriptive information and public filings on each firm in the sample. Like PAYDEX, these data were obtained from the D\&B database. However, this second category of data would be relatively accessible at a feasible cost to all but the smallest creditors. Inclusion of these variables, therefore, tells us whether D\&B-generated payment information provides predictive power above that provided by information that is otherwise readily available to creditors.

From the financial statement data we construct several variables that indicate borrower quality. A sample of the variables analyzed is given in Table 1 for the three years prior to the bankrupt/non-bankrupt classification. These data clearly show the declining nature of the bankrupt sample. The differences in the final year that are significant at the 0.01 level are net liquid balance ([cash + marketable securities - notes payable ${ }^{20}$ ), quick ratio, working capital over total assets, leverage (total liabilities over net worth), cash over total liabilities and the current ratio. The variables that will become important in the estimated logit model are the leverage, quick and net liquid balance ratios for the year prior to the firm's classification. Ratio differences were also analyzed but failed to enter the final regression model. ${ }^{21}$

\footnotetext{
${ }^{19}$ The Department of Commerce, in its 1989 release of County Business Patterns (data based on firms reporting employees with FICA coverage) reports 1,514,038 firms. These figures are not strictly comparable because of the different manner in which the two agencies count establishments.

${ }^{20}$ For a discussion of the motivation and role in the analysis of firm liquidity see Shulman and Cox (1985).

${ }^{21}$ The financial ratios are winsorized, typically at values \pm 3 standard deviations from the mean value.
} 


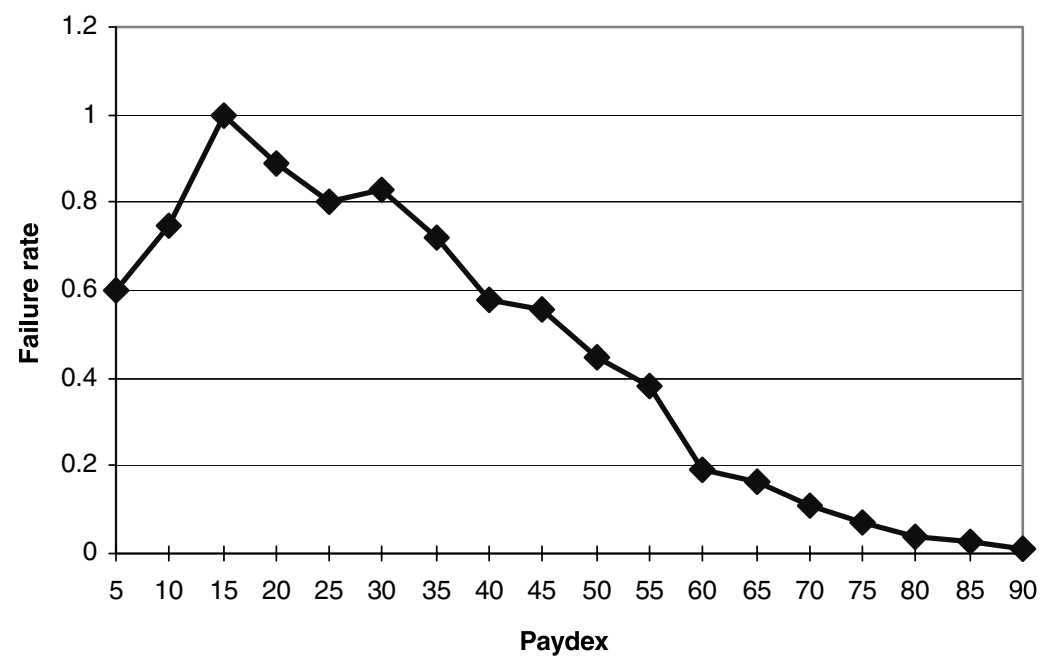

Fig. 1. Failure rate by PAYDEX.

This figure shows the in-sample failure rate as a function of the firm's PAYDEX value one year prior to the failure, non-failure classification. The overall sample failure rate is $8.8 \%$.

Table 1

Selected univariate results ${ }^{\mathrm{a}}$

\begin{tabular}{|c|c|c|c|c|c|c|c|c|c|}
\hline & \multicolumn{3}{|c|}{3 Years prior } & \multicolumn{3}{|c|}{2 Years prior } & \multicolumn{3}{|c|}{1 Year prior } \\
\hline & $\begin{array}{l}\text { Sol- } \\
\text { vent }\end{array}$ & $\begin{array}{l}\text { Bank- } \\
\text { rupt }\end{array}$ & Sig. & $\begin{array}{l}\text { Sol- } \\
\text { vent }\end{array}$ & $\begin{array}{l}\text { Bank- } \\
\text { rupt }\end{array}$ & Sig. & $\begin{array}{l}\text { Sol- } \\
\text { vent }\end{array}$ & $\begin{array}{l}\text { Bank- } \\
\text { rupt }\end{array}$ & Sig. \\
\hline Employees & 288.8 & 289.9 & & 306.1 & 306.7 & & 326.1 & 306.6 & \\
\hline Sales & 2754 & 2345 & & 3108 & 2759 & & 3405 & 2651 & \\
\hline Cash & 93.6 & 43.8 & & 97.2 & 47.4 & & 143 & 49.6 & \\
\hline AR & 253 & 134 & & 280 & 148 & & 319 & 183 & \\
\hline Inventory & 493 & 489 & & 556 & 584 & & 573 & 579 & \\
\hline Fixed assets & 236 & 138 & & 262 & 168 & & 264 & 158 & \\
\hline Total assets & 1272 & 945 & & 1434 & 1123 & & 1665 & 1242 & \\
\hline AP & 188 & 202 & & 222 & 269 & & 271 & 297 & \\
\hline Net worth & 526 & 290 & & 546 & 303 & & 616 & 284 & \\
\hline Working capital & 423 & 253 & & 477 & 206 & & 551 & 237 & \\
\hline Net liquid balance & 0.067 & -0.017 & 0.001 & 0.069 & -0.053 & 0.001 & 0.073 & -0.051 & 0.001 \\
\hline Quick & 1.881 & 0.87 & 0.001 & 1.953 & 0.698 & 0.001 & 1.989 & 0.697 & 0.001 \\
\hline Working capital/Total assets & 0.403 & 0.241 & 0.001 & 0.413 & 0.220 & 0.001 & 0.423 & 0.176 & 0.001 \\
\hline Total liab./Net worth & 0.493 & 0.732 & 0.001 & 1.57 & 2.91 & 0.001 & 2.133 & 5.522 & 0.001 \\
\hline Cash/Total liab. & 0.732 & 0.166 & 0.001 & 0.729 & 0.125 & 0.001 & 0.692 & 0.165 & 0.001 \\
\hline Sales/WC & 8.538 & 9.615 & & 8.148 & 10.745 & 0.001 & 8.216 & 9.609 & 0.072 \\
\hline Current & 3.627 & 2.276 & 0.001 & 3.682 & 2.097 & 0.001 & 3.779 & 1.967 & 0.001 \\
\hline
\end{tabular}

This table gives characteristics of the sample split into bankrupt and non-bankrupt 1, 2 and 3 years prior to this classification. Sig. indicates the significance level of the test for the equality of the two means.

${ }^{a}$ All balance sheet data in thousands. 


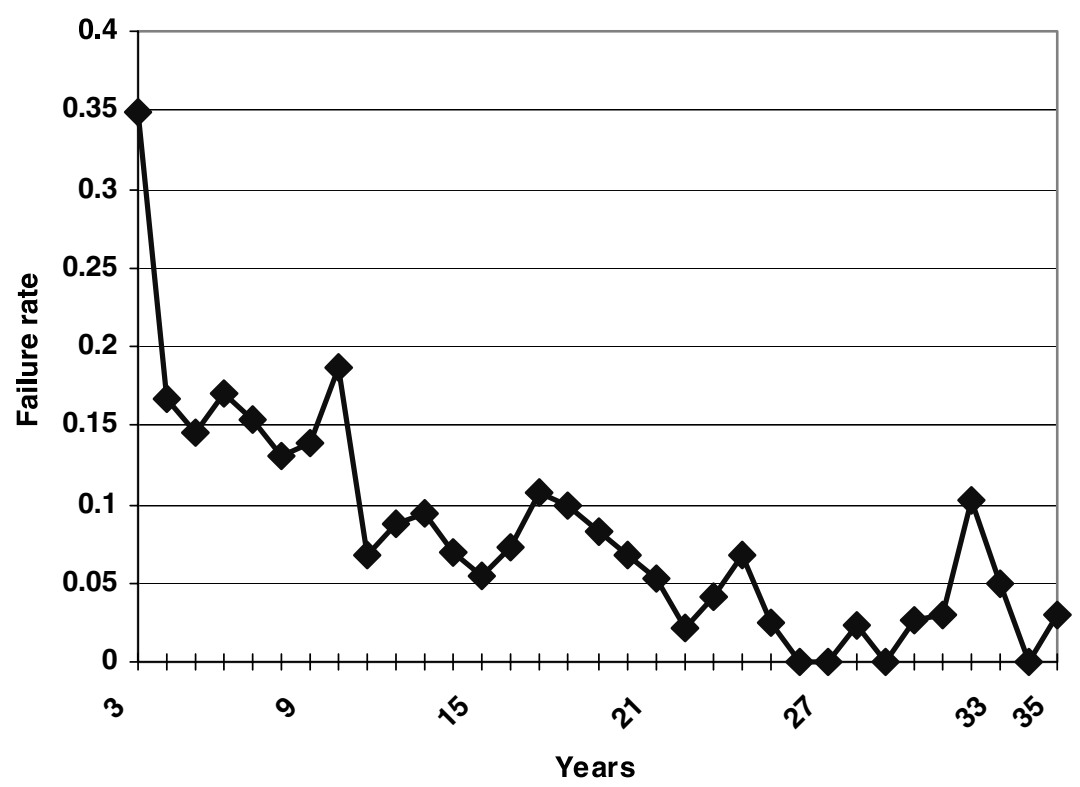

Fig. 2. Failure rate by years in business.

This figure shows the in-sample failure rate as a function of the firm's years in business measured one year prior to the failure, non-failure classification. The overall sample failure rate is $8.8 \%$.

We include a firm's AGE (years in business) because it has been associated elsewhere in the literature on business financing with firm quality (e.g., Petersen and Rajan, 1994, 1995; Berger and Udell, 1995). ${ }^{22}$ Fig. 2, which plots the relationship between firm age and firm failure rate, suggests that age has significant predictive power. We further add control variables for differences within the industry. Dummy variables were created for each 2-digit SIC code. Only the dummy variable corresponding to SIC 59 (a group containing drug stores and sporting goods) turned out to be significant. Public filings including bankruptcies, suits, judgements and UCC filings were relatively infrequent in our sample so we combined them into a single indicator variable, NEGFILE. Our final variable is COLLAT, which indicates whether the firm has any secured financing. The academic literature on bank lending suggests that riskier companies tend to borrow on a secured basis (e.g., Berger and Udell, 1990). This variable reflects any secured bank borrowings and may proxy for other information that a lender might easily have available to judge firm quality.

We test for the value of exchange-generated information in a stepwise logistic regression where the dependent variable reflects the probability that the firm will not fail. ${ }^{23}$ The results are shown in Table 2. Positive coefficients are interpreted as

\footnotetext{
${ }^{22}$ AGE is set equal to the age of the firm or the number of years since the firm has changed ownership whichever is shorter. This variable is truncated at 35 .

${ }^{23}$ The issue of logistic regression versus other classification techniques has been well analyzed in the literature; see, i.a., McFadden (1976) and Lo (1986).
} 
Table 2

Failure prediction model

\begin{tabular}{|c|c|c|}
\hline Parameter & Estimate & $t$-Statistic \\
\hline \multicolumn{3}{|c|}{ Panel A: Model estimates } \\
\hline Constant & -3.213 & -6.368 \\
\hline PAYDEX & 0.075 & 12.593 \\
\hline PAYDUM & 5.737 & 8.519 \\
\hline LEVERAGE & -0.116 & -4.658 \\
\hline QUICK & 0.246 & 2.782 \\
\hline NLB & 1.056 & 2.454 \\
\hline NEGFILE & -1.987 & -5.302 \\
\hline COLLAT & -0.503 & -2.442 \\
\hline AGE & 0.046 & 3.894 \\
\hline SIC59 & 0.625 & 2.896 \\
\hline \multicolumn{3}{|c|}{ Model $\chi^{2}=447.7$} \\
\hline \multicolumn{3}{|c|}{ Log likelihood $=-373.6$} \\
\hline \multicolumn{3}{|c|}{$\mathrm{AIC}=382.6$} \\
\hline \multicolumn{3}{|c|}{ Pseudo $R^{2}=0.736$} \\
\hline \multicolumn{3}{|c|}{ Panel B: Model classification error rates } \\
\hline Development & $10.9 \%$ & \\
\hline \multicolumn{3}{|l|}{ Validation } \\
\hline Overall & 11.7 & \\
\hline Quartile I & 14.8 & \\
\hline Quartile II & 12.3 & \\
\hline Quartile III & 11.8 & \\
\hline Quartile IV & 8.0 & \\
\hline
\end{tabular}

Panel A gives the characteristics of the failure prediction model estimated using stepwise logistic regression. All estimates are significant at the 0.01 level. AIC is the Akaike information criterion (AIC). Panel B gives the model error rates in sample ( $75 \%$ of the total number of observations) and out-of-sample pooled and by increasing size (as defined by last year's sales).

increasing the firm's estimated probability of survival. Only variables that were significant at the 0.01 level were included in the regression. The signs on each of the variables are as predicted by theory. Variables that contribute positively to firm survival are: PAYDEX, quick ratio, net liquid balance and a dummy variable for the SIC 59 industry group. Variables that increase a firm's failure probability are leverage, NEGFILE and COLLAT.

Most important for our analysis is the positive sign on the PAYDEX variable. This shows that the variable has significant incremental power even after controlling for other variables that would be available to a credit grantor. PAYDEX was the first variable to enter in the stepwise regression and has the most power to discriminate of any of the variables in our data set.

There are two basic tests of goodness-of-fit used here. ${ }^{24}$ Both are based on the log likelihood function. The first is the Akaike Information Criterion, AIC, defined by

\footnotetext{
${ }^{24}$ See Maddala (1983) for detailed development.
} 
$\mathrm{AIC}=-l(b)+K$,

where $l(b)$ is the log likelihood function evaluated at its maximum likelihood parameters and $K$ is the number of estimated parameters. The second, and closely related, criterion is the pseudo $R^{2}, \mathrm{P} R^{2}$, suggested by McFadden as a normalization of the log likelihood,

$$
\mathrm{P} R^{2}=1-\frac{l(o)}{l(b)}
$$

where $l(o)$ is the log likelihood with only the constant term different from zero. The model pseudo $R^{2}$ of 0.736 can be loosely interpreted as meaning that $73.6 \%$ of variation in the dependent variable is explained by the regression, although this interpretation is suspect for categorical dependent variables. The final statistic is the model chi-square, which is also reported in the Appendices A and B. All of these statistics indicate the model does an excellent job in-sample.

Panel B of Table 2 shows model performance on the development and the holdout sample. The model misclassification rate in-sample is $10.9 \%$; the error rate in the holdout sample is only a marginally higher $11.7 \%$. To test the robustness of this figure, the firms in the development sample were split into quartiles depending on last year's sales figures. ${ }^{25}$ This analysis shows that the model performs slightly better as firm size increases, but even in the smallest quartile the performance is very good; only $14.8 \%$ of all firms were misclassified. Generally, performance is fairly consistent across each quartile.

These results indicate that payment information generated by D\&B has significant power in predicting firm failure. Moreover, because the model includes variables for other types of information that would be available to most lenders at low cost, this result suggests that payment information generated by formal information exchanges has significant value over and above other types of information that lenders typically use in conducting their due diligence. Finally, this result also suggests that private information exchanges, at least in the case of D\&B, are capable of solving the credibility problems associated with performing their function as financial intermediaries.

\section{Conclusions}

The purpose of this paper is to investigate the value of the financial intermediaries who exchange business credit information, i.e., private information exchanges. We review the economic literature including the extant theoretical models of formal information sharing and limited empirical work in this area. We also describe the world's largest private information exchange, D\&B. In particular, we outline the type of information it generates, how it generates this information, and the form in which it sells its business credit information. Then we empirically examine for

\footnotetext{
${ }^{25}$ The respective quartiles for the most recent year's sales are $\$ 240,000 ; \$ 600,000 ; \$ 1,487,000$. Firms that did not have sales information available were deleted from this part of the testing.
} 
the first time the value of private information at the micro data level. Specifically we test whether private exchange-generated payment information adds value to lenders beyond information that is otherwise relatively easily available. Specifically, we test whether payment information collected by D\&B has significant predictive power in a failure prediction model controlling for other available information.

Our study complements and extends the extant empirical work on information sharing - principally that of Jappelli and Pagano (1999). Their analysis found that macro economic performance was positively affected by the presence of formal information exchanges. Our study likewise finds that formal information exchanges add economic value. Our results, however, are based on an analysis of the specific payment information contained in firm-level reports. Thus, our analysis focuses on the value of information exchanges to creditors in conducting their borrower due diligence.

Our main result has several implications. First, it suggests that exchange-generated information is valuable in assessing borrower quality. Second, it suggests that the value of exchange-generated information goes beyond information that is otherwise available to lenders including information contained in borrower financial statements. Third, it provides indirect evidence that private information exchanges are able to solve, at least to a considerable extent, the menu of problems that might otherwise devalue the information they collect including: credibility problems, data coverage problems and data bias problems.

\section{Acknowledgements}

The authors would like to thank Linda Allen, Allen Berger, Fari Moshirian, session participants at the 2001 Financial Management Meetings in Toronto, and at the 2001 Australasian Finance and Banking Conference for helpful comments. We are also grateful for the suggestions of an anonymous referee from the Journal of Banking and Finance. We would like to acknowledge the assistance of the members of D\&B's Technical Services Group. All errors remain the responsibility of the authors. The opinions contained in this article are those of the authors and not of the Dun and Bradstreet Corporation.

\section{Appendix A. Summary of selected information contained in the Dun and Bradstreet comprehensive report}

- Company name, address, telephone number.

- Line of business.

- Financial stress class: a classification associated with a firm failure rate.

- Credit score class: a classification associated with likelihood of late payment.

- Executive summary: contains summary information on payment performance, growth in sales, growth in net worth, whether operations are profitable, the existence of UCC filings and secured financing, years under present management, evidence of suit(s), lien(s) and judgement(s). 
- Credit capacity summary: includes summary information on sales volume, number of employees, net worth, working capital, credit levels (e.g., highest credit).

- Special events: includes description of any special event like a fire.

- Financial stress summary: provides statistical detail on the financial stress classification noted above and its interpretation.

- Credit score summary: provides statistical detail on the credit score classification noted above, a description of the factors used in the model, and an interpretation of the firm's credit score.

- Credit score norms: provides industry for companies in the same region, the same industry, the same size (measured by employees), and years in business.

- Payment trends (as summarized by PAYDEX): shows historical PAYDEX scores for the firm for past several years with the most recent year's scores shown on a monthly basis. These scores are compared to industry PAYDEX scores. (See Appendix A for more information on PAYDEX.)

- Summary of payment habits: recent payment experience categorized by size of supplier credit. For each supplier size category (e.g., suppliers that extend credit between $\$ 15,000$ and $\$ 49,999)$, the CR shows "number of experiences", "total amount" and "\% dollars within terms".

- Payment analysis by industry: indicates number of payment experiences in the D\&B file and the number of experiences in the most recent 12 and 3 month periods. Summarizes payment experiences by industry including number of experiences, dollar amount, highest credit, and aging information (i.e., amount within terms, slow 1-30, slow 31-60, slow 61-90, and 91+).

- Public filings summary: lists number an most recent filing date for bankruptcy proceedings, judgements, liens, suits and UCC filings.

- Public filings detail: provides detail on each filing.

- Business background: includes historical information about firm and officers, and information about firm operations.

- Banking relationships: provides information about deposit levels and bank borrowing.

Note: The exhibit summarizes information contained the sample Comprehensive Report shown on D\&B's website. This represents a report on a single company and is based on data in the D\&B database on that company. Some of this information, particularly financial information, is not be available for all companies in the D\&B database. With the exception of the first two bullet points, the underlined titles are exact quotations of the selected topic headings shown in the sample D\&B Comprehensive Report in the D\&B website.

\section{Appendix B. D\&B payment index: PAYDEX}

Source: Sample Comprehensive Report from D\&B (2002).

This exhibit shows the interpretation of PAYDEX in terms of representative payment behavior. The calculation of PAYDEX requires at least four trade experiences within the last 13 months from different credit grantors. 


\begin{tabular}{ll}
\hline PAYDEX & Payment \\
\hline 100 & Anticipate \\
90 & Discount \\
80 & Prompt \\
70 & Slow to 15 days \\
50 & Slow to 30 days \\
40 & Slow to 60 days \\
30 & Slow to 90 days \\
20 & Slow to 120 days \\
\hline
\end{tabular}

Source: D\&B Technical Services Group.

\section{References}

Altman, E.I., 1968. Financial ratios, discriminant analysis and prediction of corporate bankruptcy. Journal of Finance, 589-610.

Altman, E.I., 1989. Measuring corporate bond mortality and performance. The Journal of Finance 44, 909-922.

Asquith, P., Mullins, W., Wolff, E.D., 1989. Original issue high yield bonds; Aging analysis of defaults, exchanges and calls. Journal of Finance 44, 932-952.

Beaver, W., 1966. Financial ratios as predictors of failure. Journal of Accounting Research (Supplement), 71-102.

Berger, A.N., Udell, G.F., 1990. Collateral, loan quality, and bank risk. Journal of Monetary Economics $25,21-42$.

Berger, A.N., Udell, G.F., 1995. Relationship lending and lines of credit in small firm finance. The Journal of Business, 351-382.

Berger, A.N., Udell, G.F., 1998. The economics of small business finance: The roles of private equity and debt markets in the financial life cycle. Journal of Banking and Finance, 613-673.

Biais, B., Gollier, C., 1997. Trade credit and credit rationing. Review of Financial Studies 10, 903-937.

Boot, A.W.A., Thakor, A.V., Udell, G.F., 1991. Credible commitments, contract enforcement problems and banks: Intermediation as credibility assurance. Journal of Banking and Finance, 605-632.

Boyd, J., Prescott, E.C., 1986. Financial intermediary-coalitions. Journal of Economic Theory 38, $211-$ 232.

Brennan, M.J., Maksimovic, V., Zechner, J., 1988. Vendor financing. The Journal of Finance 43, 11271141.

Cantor, R., Packer, F., 1994. The credit rating industry. Quarterly Review, Federal Reserve Bank of New York, 1-27.

Carruthers, B.G., Cohen, B., 2000. Knowledge of failure or failure of knowledge? Bankruptcy, credit and credit reporting in the 19th-century US, Northwestern University Working Paper.

Cheng, B., Titterington, D.M., 1994. Neural networks: A review from a statistical perspective. Statistical Science 8 (1), 2-34.

Clarke, P.S., 1996. Asset Based Lending. Irwin, Chicago.

Cook, L., 1999. Trade finance, bank finance, and capital market imperfections, Working Paper, Harvard University.

Diamond, D.W., 1984. Financial intermediation and delegated monitoring. Review of Financial Studies $51,393-414$.

Dun \& Bradstreet, 2002. D\&B Website, www.dandb.com.

Edmister, R.O., 1972. An empirical test of financial ratio analysis for small business failure prediction. Journal of Financial and Quantitative Analysis 7, 1477-1493.

Ferris, J.S., 1981. A transactions theory of trade credit use. Quarterly Journal of Economics 96, 243-270. 
Gilson, S.C., John, K., Lang, L.H.P., 1990. Troubled debt restructurings: An empirical study of private reorganization of firms in default. Journal of Financial Economics 26, 315-353.

Jappelli, T., Pagano, M., 1999. Information sharing, lending and defaults: Cross country evidence, Centre for Economic Policy Research, Discussion Paper 2184.

Kallberg, J., Udell, G.F., 2002. Private business information exchange in the United States. In: Miller, M. (Ed.), Credit Reporting Systems and the International Economy. MIT Press, Cambridge, MA.

Kaplan, R., Urwitz, G., 1979. Statistical models of bond ratings: A methodological inquiry. Journal of Business 52, 231-262.

Keasey, K., Watson, R., 1987. Non-financial symptoms and the prediction of small company failure: A test of Argenti's hypotheses. Journal of Business Finance and Accounting 14, 353-355.

Klein, D.B., 1992. Promise keeping in the great society: A model of credit information sharing. Economics and Politics 4, 117-136.

Lo, A., 1986. Logit versus discriminant analysis: A specification test and application to corporate bankruptcies. Journal of Econometrics 31, 151-178.

Maddala, G.S., 1983. Limited-Dependent and Qualitative Variables in Econometrics. Cambridge University Press, Cambridge.

Martin, D., 1977. Logistic analysis and early warning systems for bank supervision. Journal of Banking and Finance 1, 249-276.

McFadden, D., 1976. A comment on discriminant analysis 'versus' logit analysis. Annals of Economic and Social Measurement 5, 511-523.

Mian, S., Smith, C., 1992. Accounts receivable management policy: Theory and evidence. Journal of Finance 47, 169-200.

Moon, C., Stotsky, J., 1993. Testing the differences between the determinants of Moody's and Standard and Poor's ratings. Journal of Applied Econometrics 8, 51-69.

Newman, J.W., 1997. Dun \& Bradstreet: For the promotion and protection of trade. In: Klein, D. (Ed.), Reputation: Studies in the Voluntary Elicitation of Good Conduct. University of Michigan Press, Ann Arbor, MI.

Orgler, Y., 1970. A credit scoring model for commercial loans. Journal of Money, Credit, and Banking 2, $435-445$.

Padilla, A.J., Pagano, M., 1997. Endogenous communication among lenders and entrepreneurial incentives. The Review of Financial Studies 10 (1), 205-236.

Padilla, A.J., Pagano, M., 1999. Sharing default information as a borrower discipline device. University of Salerno: CSEF Working Paper no. 21.

Pagano, M., Jappelli, T., 1993. Information sharing in credit markets. The Journal of Finance 43, 1693 1718.

Petersen, M.A., Rajan, R.G., 1994. The benefits of firm-creditor relationships: Evidence from small business data. Journal of Finance 49, 3-37.

Petersen, M.A., Rajan, R.G., 1995. The effect of credit market competition on lending relationships. Quarterly Journal of Economics 110, 407-443.

Petersen, M.A., Rajan, R.G., 1997. Trade credit: Theories and evidence. The Review of Financial Studies 10, 661-691.

Queen, M., Roll, R., 1987. Firm mortality: Using market indicators to predict survival. Financial Analyst Journal, May/June, 9-26.

Shulman, J., Cox, R., 1985. An integrative approach to working capital management. Journal of Cash Management (March-April).

Shumway, T., 2001. Forecasting bankruptcy more accurately: A simple hazard model. Journal of Business 74, 101-124.

Smith, J.K., 1987. Trade credit and information asymmetries. Journal of Finance 42, 863-872.

Theodossiou, P.T., 1993. Predicting shifts in the mean of a multivariate time series process: An application in predicting business failures. Journal of the American Statistical Association 88, 422, 441-449.

Wilson, B., Kallberg, J., 1991. An analysis of firm failure dynamics. Salomon Center Working Paper. Stern School of Business, New York University. 